\title{
VARIANT OP EEN POPULAIRE METHODE VAN AFSCHRIJVEN
}

\author{
door Tj. S. Visser
}

1. Het moge waar zijn dat afschrijving van een bedrijfsmiddel met bedragen welke een bepaald percentage uitmaken van de boekwaarde, een afschrijvingssysteem is waar niet veel verstand achter zit, het is dan toch maar waar dat juist dit systeem populair is. Populair om fiscale redenen. In de ambtelijke leidraad bij het Besluit inkomstenbelasting wordt gezegd, dat toepassing er van goed koopmansgebruik mag heten. En later heeft de Minister van Financiën zelfs overgang op dit systeem goedgekeurd voor hen, die een ander systeem aanhingen: bij aanschaffing van nieuwe bedrijfsmiddelen mochten zij, óók voor de oude objecten, alsnog overstappen op het afschrijven met een vast percentage van de boekwaarde. Derhalve zijn fiscaal alle hekken van de dam; voeg daarbij dat de methode het in gunstige jaren zo aantrekkelijke heeft van de zwaarste afschrijvingen het eerst te laten komen, en de populariteit zal duidelijk zijn.

2. Helaas heeft het systeem enkele technische bezwaren. Het is eenvoudig niet mogelijk indien de residuwaarde van het object nihil (goodwill) of negatief is; omdat (het vaste percentage $100 \mathrm{i}$ (d.w.z. het vaste pecunage i) genoemd en de aanschaffingsprijs 1) de vorm $\left(1-\right.$ i) ${ }^{n}$ nimmer nul of negatief kan worden. Voorts is het ietwat vreemd dat de laatste afschrijvingen nog al eens erg gering uitvallen. Aan een geheel andersoortig bezwaar, dat namelijk een kleine variatie in de schatting van de (positieve) residuwaarde een betrekkelijk grote verandering mee kan brengen in de benodigde $i$, gaan wij nu maar voorbij.

3. $\mathrm{Nu}$ is het eigenlijk heel eenvoudig om tegemoet te komen aan het eerste bezwaar. Slechts de volgende kunstgreep is nodig. Men voege aan de jaarlijkse afschrijving een, relatief gering, vast bestanddeel toe. M.a.w. men kieze als systeem: de jaarafschrijving bestaat uit een klein vast bestanddeel vermeerderd met een bedrag hetwelk een zeker percentage van de boekwaarde uitmaakt. Dit systeem is zeer wel toepasbaar ook bij negatieve of nul-residuwaarde.

Het stemt dan echter wat onbehaaglijk, dat bedoeld vast bestanddeel zo maar volstrekt willekeurig zou kunnen worden gekozen. Doch die willekeur kunnen wij matigen en wel door aandacht te schenken aan het tweede bezwaar der ,.gewone" methode: het minuscule van de laatste afschrijvingen. Men kan de eis stellen dat de slotafschrijving niet geringer zij dan ongeveer een tiende (bijvoorbeeld) van de eerste afschrijving. Wil het werkelijk zo uitkomen dan zal het vaste bestanddeel van de afschrijvingenreeks een bepaalde grootte moeten hebben. Dat is duidelijk; en laat zich ook vrij gemakkelijk narekenen. Nu kan men wel tegenwerpen dat wij de onbehaaglijk stemmende willekeur alleen maar hebben verschoven, verschoven naar het begrenzen van de slotaf schrijving (in ons voorbeeld: een tiende ongeveer van de eerste afschrijving). Doch dat is dan althans een willekeur, een keuze doen, waarbij zich iets denken laat, en waarover te praten valt.

4. Als variant op het populaire systeem stellen wij derhalve voor: de jaarafschrijving bestaat uit een bedrag gelijk aan een vast pecunage $i$ van de boekwaarde, vermeerderd met een relatief klein vast bedrag $t$ 
hetwelk zo gekozen wordt dat de slotafschrijving niet geringer wordt dan (bijvoorbeeld) ongeveer een tiende part van de eerste afschrijving.

Heeft men dan de levensduur $n$ geschat en de residuwaarde $r$ (aanschafprijs 1 gesteld), dan laten zich formules afleiden voor de te bepalen getallen $i$ (het vaste pecunage) en $t$ (het vaste bedragje). Wij zullen dat afleiden hier achterwege laten, doch wel de formules meedelen. Vooraf moeten wij de lezer echter op een bijzonderheid wijzen. Het bleek ons dat het formule-stel vrij elegant werd indien bij het begrenzen van de slotafschrijving een wat verrassende formulering gekozen werd. Stel men vermoedt dat voor de i wel iets in de buurt van 0,2 gevonden zal worden; en stel dat men bedoelt, gelijk in ons voorbeeld, de slotafschrijving niet geringer te doen zijn dan "ongeveer een tiende" van de eerste. Men formulere dan dit "ongeveer een tiende" als volgt:

$$
\frac{0,08}{1-\mathbf{i}}
$$

Als $\mathrm{i}$ inderdaad in de buurt van 0,2 ligt, staat hier werkelijk niets anders dan: een tiende; en dan kan men veilig zeggen (zolang i nog niet berekend is) dat er staat: ,ongeveer een tiende". Algemener (als wij de 0,08 uit dit voorbeeld aanduiden met f): men gebruike bij het stellen van de grens-eis de breuk:

$$
\frac{\mathrm{f}}{1-\mathrm{i}}
$$

De formules worden nu:

$$
\begin{aligned}
& \mathrm{i}=1-\stackrel{\mathrm{V} f}{ } \\
& \mathrm{t}=\mathrm{i} \frac{\mathrm{f}-\mathrm{r}}{1-\mathrm{f}}
\end{aligned}
$$

5. Wie graag met formules experimenteert zal opmerken dat de toeslag $t$ verdwijnt (d.w.z. het gewone stelsel komt te voorschijn) indien f gelijk is aan $\mathbf{r}$ (let wel: $\mathbf{r}$ is de residuwaarde waarbij de aanschafkosten 1 heten, dus $r$ geeft weer de verhouding van residu tot aanschaf). Die uitkomst laat zich ook beredeneren. Men kan hierin tevens een grens zien bij de keuze van f; f zij niet kleiner dan $r$.

6. Men zegge niet dat er geen verstand zit in deze variant. Want wel is dat zo, doch dat is niet vreemd want gelijk wij in de aanvang opmerkten, de methode zelf heeft ook niet veel verstand achter zich. De variant echter breidt haar toepasbaarheid uit. En vermindert het euvel van de belachelijk kleine laatste afschrijvingen. Hetgeen toch wel echt een verbetering met zin mag heten. - Voorts verdient het de aandacht dat de kunstgreep uit 3 toch wel iets beters is dan enkel een kunstgreep. Want het blijkt. dat hoofdsysteem en variant zich samen laten vangen onder één omschrijving die waarlijk niet onwezenlijk is. Van beide geldt namelijk dat ze leiden tot afschrijuingen welke een afdalende meetkundige reeks (reden 1 - i) vormen. Hetgeen de lezer gelove of zelf bewijze.

7. Wij besluiten met een voorbeeld. Een installatie kost $f$ 100.000; levensduur begroot op 15 jaar; residuwaarde negatief $f 1000$ door slopingskosten. Afschrijvingssysteem deze variant; dus vast \% van boekwaarde, plus toeslagje. Waarbij gesteld wordt dat de slotafschrijving niet geringer moet zijn dan 


$$
\frac{1 / 12}{1-i}
$$

maal de eerste afschrijving.

Derhalve zijn gegeven, als de aanschafprijs 1 wordt genoemd:

$$
\begin{aligned}
& \mathrm{r}=-0,01 \\
& \mathrm{n}=15 \\
& \mathrm{f}=1 / 12
\end{aligned}
$$

De formules leveren dan:

$$
\mathrm{i}=0,15 \text { en } \mathrm{t}=0,015
$$

De eerste afschrijving wordt $f 15.000$ plus een toeslag van $f 1500$, is $f$ 16.500. De volgende afschrijvingen kan men met de definitie van het systeem afleiden of, korter, met behulp van de boven aangeduide eigenschap, dat elke afschrijving gelijk is aan 0,85 (immers 1 - i) maal de voorgaande. De rij der afschrijvingen wordt:
1. $f 16.500$
2. 14.000
3. 11.900
4. 10.200
5. 8.700
6. $\quad 7.400$
7. 6.300
8. $\quad 5.400$
9. 4.600
10. $\quad 3.900$
11. 3.300
12. 2.800
13. 2.400
14. 2.000
$15 . \quad 1.700$

$f 101.100$ is de som der afschrijvingen, dus $f$ 100. te veel (door afrondingen).

8. N.B. Voor een voorlopige ruwe schatting van i (ten behoeve van het vooraf begrenzen van de kleinheid der slotafschrijving) kan men gerust nemen $i=2 / n$. Dus in ons voorbeeld $i=2 / 15$. Vandaar dat men, bedoelde begrenzing willende hebben in de buurt van een tiende, en die grenseis willende gieten in de door ons voorgeschreven vorm, men voor $\mathrm{f}$ iets als $1 / 12$ zal nemen. Gelijk wij in het voorbeeld deden. 